\title{
PENGARUH STRATEGI PEMBELAJARAN DAN KOMUNIKASI INTERPERSONAL TERHADAP HASIL BELAJAR PENDIDIKAN KEWARGANEGARAAN SISWA MTs SWASTA KECAMATAN KUALUH HULU KABUPATEN LABUHANBATU UTARA
}

\author{
Lilik Munawaroh ${ }^{1}$, Abdul Hamid, K. $^{2}$ \\ Guru MTs Islamiyah Londut ${ }^{1}$, Pascasarjana Universitas Negeri Medan ${ }^{2}$ \\ lilik_munawaroh@yahoo.com ${ }^{1}$.abdul_hamid@yahoo.com ${ }^{2}$
}

\begin{abstract}
Abstrak: Tujuan penelitian ini adalah untuk mengetahui: (1) hasil belajar Pendidikan Kewargangeraan (PKn) siswa yang diajar dengan menggunakan strategi pembelajaran inkuiri sosial lebih tinggi daripada strategi pembelajaran ekspositori, (2) hasil belajar PKn antara siswa dengan karakterk komunikasi interpersonal tinggi lebih tinggi daripada interpersonal rendah, dan (3) interaksi antara strategi pembelajaran dan komunikasi interpersonal terhadap hasil belajar PKn. Populasi penelitian adalah seluruh siswa kelas VIII MTs Islamiyah Londut terdiri dari 3 kelas dengan jumlah siswa adalah 108.Teknik analisis adalah Anava dua jalur pada taraf signifikansi $\alpha=0,05$ yang dilanjutkan dengan uji Scheffe. Hasil penelitian adalah: (1) ratarata hasil belajar PKn siswa yang diajar dengan strategi pembelajaran inkuiri sosial lebih tinggi daripada rata-rata hasil belajar PKn siswa yang diajar dengan strategi pembelajaran ekspositori, (2) rata-rata hasil belajar PKn siswa dengan komunikasi interpersonal tinggi lebih tinggi daripada hasil belajar PKn siswa dengan komunikasi interpersonal rendah, dan (3) terdapat interaksi antara strategi pembelajaran dan komunikasi interpersonal terhadap hasil belajar PKn.
\end{abstract}

Kata Kunci: strategi pembelajaran, komunikasi interpersonal, pendidikan kewarganegaraan

Abstract: The purpose of this study was to determine: (1) the learning outcomes of Education Kewargangeraan (Civics) students who are taught using a strategy of inquiry learning social is higher than the strategy expository, (2) the results of learning civics among students with karakterk interpersonal communication high higher interpersonal rather than low, and (3) the interaction between the learning strategies and interpersonal communication on learning outcomes Civics. The study population was all students of class VIII MTs Islamiyah Londut consists of three classes with the number of students is 108.Teknik analysis is Anava two lanes at significance level $\alpha=$ 0.05, followed by Scheffe test. Results of the study are: (1) an average of learning outcomes Civics students who are taught strategies inquiry learning social is higher than the average learning outcomes Civics students taught with instructional strategies expository, (2) the average results of learning civics students with communication high interpersonal higher than Civics learning outcomes of students with low interpersonal communication, and (3) there is no interaction between the learning strategies and interpersonal communication on learning outcomes Civics.

Keywords: learning strategies, interpersonal communication, civic education

\section{PENDAHULUAN}

Salah satu strategi yang dapat diterapkan pada pembelajaran PKn adalah strategi pembelajaran inkuiri sosial. Penerapann strategi pembelajaran inkuiri sosial pada pembelajaran $\mathrm{PKn}$ memberikan pengalaman langsung kepada siswa, tujuannya adalah membina siswa dalam rangka mengembangkan aspek kognitif, afektif dan psikomotorik siswa secara menyeluruh dan berinteraksi dengan teman dan lingkungannya. Pembelajaran inkuiri sosial dalam bidang studi PKn menekankan pembelajaran di mana siswa menemukan sendiri yang dipelajarinya, bukan mengetahui dari guru saja.

Sedangkan pada strategi pembelajaran ekspositori pada pembelajaran PKn lebih menekankan penyampaian informasi atau ceramah yang dilakukan guru, sehingga terdapat kecenderungan siswa hanya sebagai pendengar pasif dan pencatat saja di mana fungsi guru merupakan satu-satunya sumber belajar sehingga penumpukan informasi yang disampaikan guru melalui ceramah sehingga kondisi yang demikian membuat siswa jenuh 
dan berakibat kepada pencapaian hasil belajar yang kurang maksimal.

Di lain pihak, perolehan hasil belajar suatu kegiatan pembelajaran juga dipengaruhi oleh karakteristik siswa dalam hal ini adalah komunikasi interpersonal siswa dalam belajar, dalam hal ini komunikasi interpersonal dibedakan atas komunikasi interpersonal tinggi dan komunikasi interpersonal rendah. Komunikasi interpersonal yaitu kemampuan individu melakukan komunikasi bertukar informasi, pikiran, ide, dan perasaan yang berlangsung antar individu dalam rangka supaya terjalin hubungan baik dan harmonis. Komunikasi interpersonal yang baik maka akan tercermin dan termanifestasikan ke dalam menjalin komunikasi.

Materi PKn berisi konsep-konsep dan penerapannya sehingga komunikasi interpersonal menjadi urgen. Siswa yang memiliki komunikasi interpersonal yang tinggi juga akan lebih mudah dalam mempelajari materi PKn, sedangkan pada siswa yang memiliki komunikasi interpersonal yang rendah akan mengalami kesulitan dalam hal mempelajari materi PKn. Siswa yang memiliki komunikasi interpersonal yang tinggi juga relatif akan lebih mudah mengolah informasi dan mengemukakan ide dan pemikiran yang ada dibenaknya bila dibandingkan dengan siswa yang memiliki komunikasi interpersonal rendah.

Hamalik (2003) menjelaskan belajar adalah modifikasi atau memperteguh kelakuan melalui pengalaman. Sedangkan Mulyati (2005) menjelaskan bahwa belajar adalah merupakan suatu usaha sadar individu untuk mencapai tujuan peningkatan diri atau perubahan diri melalui latihan-latihan dan pengulanganpengulangan dan perubahan yang terjadi bukan karena peristiwa kebetulan.

Syah (2004) menjelaskan belajar adalah suatu perubahan yang terjadi dalam diri organisme, manusia atau hewan, disebabkan oleh pengalaman yang dapat mempengaruhi tingkah laku organisme tersebut. Sedangkan Suryabrata (2002) menjelaskan belajar merupakan suatu proses perubahan tingkah laku sebagai suatu hasil interaksi dengan lingkungannya dalam memenuhi kebutuhannya dengan ciri-ciri: (1) perubahan terjadi secara sadar, (2) perubahan dalam belajar terjadi bersifat kontinu dan fungsional, (3) perubahan dalam belajar terjadi bersifat positif dan aktif artinya perubahan itu senantiasa bertambah dan tertuju untuk memperoleh sesuatu yang lebih baik dari sebelumnya, (4) perubahan dalam belajar bukan bersifat sementara, tetapi bersifat permanen, (5) perubahan dalam belajar bertujuan terarah, dan (6) perubahan dalam belajar mencakup seluruh aspek tingkah laku.

Suryabrata (2002) menjelaskan bahwa di dalam belajar terdapat beberapa hal yang pokok untuk dipahami yaitu: (1) belajar membawa perubahan dalam arti behavioural change (perubahan tingkah laku), aktual maupun potensial, (2) perubahan tersebut pada pokoknya adalah didapatkannya kecakapan baru, (3) perubahan itu terjadi karena usahausaha atau dengan sengaja.

Djamarah dan Zain (2002) menjelaskan bahwa hasil belajar adalah penguasaan peserta didik terhadap bahan/materi pelajaran yang telah diberikan ketika proses mengajar berlangsung. Gagne dan Briggs (1979) mengemukakan bahwa hasil belajar dapat dikelompokkan ke dalam lima kategori, yaitu keterampilan intelektual, strategi kognitif, informasi verbal, kemampuan motorik dan sikap.

Rohani dan Ahmadi (2005) menyatakan bahwa penilaian hasil belajar bertujuan melihat kemampuan belajar peserta didik dalam hal penguasaan materi ajar yang telah dipelajarinya sesuai dengan tujuan-tujuan yang telah ditetapkan. Tujuan merupakan sasaran atau objek yang akan dicapai. Sasaran atau objek evaluasi hasil belajar adalah perubahan tingkah laku yang mencakup bidang kognitif, afektif dan psikomotor secara seimbang. Masingmasing bidang terdiri sejumlah aspek. Aspekaspek tersebut sebaiknya dapat diungkapkan melalui penilaian tersebut. Dengan demikian dapat diketahui tingkah laku mana yang sudah dikuasai oleh siswa dan mana yang belum.

Berkaitan dengan bidang studi PKn penekanan ketercapaian hasil belajar adalah pada aspek afektif. Krathwohl, Bloom dan Masria (1964) mengembangkan taksonomi ini yang berorientasi kepada perasaan atau afektif. Taksonomi ini menggambarkan proses seseorang di dalam mengenali dan mengadopsi suatu nilai dan sikap tertentu yang menjadi pedoman baginya dalam bertingkah laku. Krathwohl, Bloom dan Masria (1964) membaginya atas lima kategori/tingkatan yaitu: pengenalan (receiving), pemberian respon (responding), penghargaan terhadap nilai (valuing), pengorganisasian (organization) dan pengamalan (characterization). 
Wena (2009) menjelaskan strategi pembelajaran berarti cara dan seni untuk menggunakan semua sumber belajar dalam upaya membelajarkan siswa. Sebagai suatu cara, strategi dikembangkan dengan kaidahkaidah tertentu sehingga membentuk suatu bidang pengetahuan, strategi pembelajaran dapat dipelajari dan kemudian diaplikasikan dalam kegiatan pembelajaran. Sebagai suatu seni, strategi pembelajaran kadang-kadang secara implisit dimiliki seseorang tanpa pernah belajar secara formal tentang ilmu strategi pembelajaran.

Romizowski (1981) menekankan bahwa setiap strategi pembelajaran yang dikembangkan selalu mencerminkan posisi teoritis yang dianut tentang bagaimana seharusnya pembelajaran itu dilaksanakan. Oleh karena itu, tenaga pengajar sebagai penyelenggara kegiatan pembelajaran dituntut mampu mengupayakan terjadinya interaksi peserta didik dengan komponen sistem pembelajaran yang lain secara optimal. Strategi pembelajaran merupakan rangkaian kegiatan pembelajaran dan penciptaan kondisi belajar peserta didik secara aktif. Apabila strategi pembelajaran dapat mendorong timbulnya aktifitas peserta didik maka proses belajar peserta didik juga akan semakin banyak terjadi dan pada gilirannya nanti hasil belajar peserta didik akan semakin meningkat.

Gagné dan Briggs (1979) mengatakan bahwa sistem instruksional adalah suatu set peristiwa yang mempengaruhi peserta didik sehingga terjadi proses belajar. Suatu set peristiwa itu mungkin dilakukan oleh pengajar sehingga disebut pembelajaran, mungkin juga dilakukan oleh peserta didik sendiri dengan menggunakan buku, gambar, program televisi atau kombinasi berbagai media, baik oleh pengajar maupun oleh peserta didik sendiri, kegiatan itu haruslah terencana secara sistematik untuk dapat disebut kegiatan kegiatan pembelajaran.

Dick, Carey dan Carey (2005) mengatakan bahwa strategi pembelajaran memuat lima komponen utama yaitu: (1) aktivitas pembelajaran pendahuluan, (2) penyampaian informasi, (3) partisipasi peserta didik, (4) tes, dan (5) kegiatan lanjutan. Suparman (2001) mendefinisikan strategi pembelajaran sebagai perpaduan dari (1) urutan kegiatan instruksional, (2) cara pengorganisasian materi pengajaran dan peserta didik, (3) peralatan dan bahan, dan (4) waktu yang digunakan dalam proses pembelajaran. Kedua definisi tersebut pada prinsipnya lebih menekankan pada aspek komponen dan prosedur pengajaran.

Romizowski (1981) berpendapat bahwa strategi pembelajaran merupakan suatu pendekatan menyeluruh yang dapat dibedakan menjadi dua strategi dasar, yaitu ekspositori (penjelasan) dan inquiri/diskoveri (penemuan). Kedua strategi ini dapat dipandang sebagai dua ujung yang sejalan dalam suatu kontinum strategi. Hal ini erat sekali kaitannya dengan pendekatan deduktif di mana strategi ini dimulai dengan penyajian informasi mengenai prinsip atau kaidah kemudian dikuti dengan tes penguasaan dan penerapan dalam bentuk contoh dan penerapan pada situasi tertentu, sedangkan strategi inquiri/diskoveri didasarkan pada teori belajar pengalaman yang disebut juga teori belajar pengalaman. Dari penjelasan ini dapat disimpulkan bahwa strategi pembelajaran merupakan perpaduan dari urutan kegiatan, metode, media dan waktu yang digunakan oleh pengajar dan peserta didik dalam suatu proses pembelajaran untuk mencapai hasil yang telah ditentukan.

Dalam menggunakan strategi pembelajaran hal utama yang harus diperhatikan adalah karakteristik peserta didik. Seels dan Richey (1994) berpendapat bahwa karakteristik peserta didik adalah segi-segi latar belakang pengalaman yang berpengaruh terhadap efektivitas proses belajarnya. Dick, Carey dan Carey (2005) menjelaskan bahwa dalam pengembangan pembelajaran penting sekali mempertimbangkan karakteristik peserta didik untuk memilih pendekatan yang sesuai dalam kegiatan pembelajaran. Langkah-langkah yang ditempuh sebagai prosedur desain dan pengembangan pembelajaran, yaitu: (1) analisis kebutuhan untuk mengidentifikasi tujuan pembelajaran umum, (2) melakukan analisis instruksional, (3) menganalisis karakteristik peserta didik dan konteks, (4) pengembangan instrumen penilaian, (5) mengembangkan strategi pembelajaran, (6) mengembangkan dan memilih bahan-bahan pembelajaran, (7) merancang dan menyusun evaluasi formatif pembelajaran, (8) merancang dan menyusun evaluasi sumatif pembelajaran, dan (9) revisi untuk setiap langkah pengembangan pembelajaran.

Teori belajar yang mendukung strategi pembelajaran inkuiri sosial adalah teori belajar kognitif-konstruktivis. Hal ini terlihat dari salah 
satu teori perkembangan kognitif Piaget dan Vygotsky, yaitu tentang penekanan pada hakikat sosiokultural dari pembelajaran. Slavin (2009) menjelaskan Piaget membedakan perkembangan kognitif seorang anak menjadi empat taraf, yaitu (1) taraf sensori motor, (2) taraf praoperasional, (3) taraf operasional konkrit, dan (4) taraf operasional formal.

Implikasi teori kognitif Piaget pada pendidikan dijelaskan Slavin (2009) sebagai berikut: (1) memusatkan perhatian kepada berfikir atau proses mental anak, tidak sekedar kepada hasilnya. Selain kebenaran jawaban siswa, guru harus memahami proses yang digunakan anak sehingga sampai pada jawaban tersebut. Pengalaman-pengalaman belajar yang sesuai dikembangkan dengan memperhatikan tahap fungsi kognitif dan hanya jika guru penuh perhatian terhadap metode yang digunakan siswa untuk sampai pada kesimpulan tertentu, barulah dapat dikatan guru berada dalam posisi memberikan pengalaman yang dimaksud, (2) mengutamakan peran siswa dalam berinisiatif sendiri dan keterlibatan aktif dalam kegiatan belajar. Dalam kelas, Piaget menekankan bahwa pengajaran pengetahuan jadi (ready made knowledge) tidak mendapat tekanan, melainkan anak didorong menemukan sendiri pengetahuan itu melalui intraksi spontan dengan lingkungan. Oleh karena itu, selain mengajar secara klasik, guru mempersiapkan keanekaragaman kegiatan secara langsung dengan dunia fisik, dan (3) memaklumi akan adanya perbedaan individual dalam hal kemajuan perkembangan. Teori Piaget mengasumsikan bahwa seluruh siswa tumbuh dan melewati urutan perkembangan yang sama, namun pertumbuhan itu berlangsung pada kecepatan yang berbeda. Oleh karena itu harus melakukan upaya untuk mengatur aktivitas di dalam kelas yang terdiri dari individu-individu kedalam bentuk kelompok-kelompok kecil siswa dari pada aktivitas dalam bentuk klasikal.

Sanjaya (2007) menjelaskan strategi pembelajaran inkuiri sosial merupakan strategi pembelajaran yang berada dalam kelompok sosial (social family) subkelompok konsep masyarakat (concept of society). Subkelompok ini didasarkan pada asumsi bahwa strategi pembelajaran bertujuan untuk mengembangkan anggota masyarakat ideal yang dapat hidup dan dapat mempertinggi kualitas kehidupan masyarakat. Oleh karena itulah siswa harus diberi pengalaman yang memadai bagaimana caranya memecahkan persoalan-persoalan yang muncul di masyarakat. Melalui pengalaman itulah setiap individu akan dapat membangun pengetahuan yang berguna bagi diri dan masyarakatnya. Oleh karena itu strategi pembelajaran inkuiri sosial dipandang sebagai suatu strategi pembelajaran yang berorientasi kepada pengalaman siswa.

Penerapan strategi pembelajaran inkuiri sosial dijelaskan Wena (2009) sebagai upaya memecahkan masalah dalam pembelajaran sosial karena: (1) strategi pembelajaran inkuiri sosial dirancang untuk meningkatkan kemampuan dan keterampilan siswa dalam memecahkan masalah-masalah sosial, (2) beberapa hasil penelirian menunjukkan bahwa strategi pembelajaran inkuiri sosial terbukti efektif meningkatkan kemampuan dan keterampilan siswa dalam memecahkan masalah-masalah sosial, dan (3) strategi pembelajaran inkuiri sosial merupakan sinkronisasi antara teori mengajar dan teori belajar yang memiliki prosedur yang sistematis dan mudah diterapkan oleh pengajar.

Sanjaya (2007) bahwa pembelajaran ekspositori adalah strategi pembelajaran yang menekankan pada proses penyampaian materi secara verbal dari seorang guru kepada sekelompok siswa dengan maksud agar siswa dapat menguasai materi pelajaran secara optimal. Guru menyampaikan informasi dan siswa diharapkan dapat memproses informasi tersebut serta dapat menjelaskan kembali sebagaimana yang telah disampaikan guru. Teknik yang sering digunakan guru adalah teknik kuliah atau ceramah kadang-kadang diskusi, penampilan gambar-gambar dan mendengarkan tanggapan-tanggapan siswa. Siswa diuji dan dievaluasi dengan untuk mengidentifikasi kemampuan siswa.

$$
\text { Rohani dan Ahmadi }
$$

menjelaskan pembelajaran ekspositori bertolak dari pandangan bahwa tingkah laku siswa dan distribusi pengetahuannya dikontrol dan ditentukan oleh guru. Oleh sebab itu hakekat mengajar menurut pandangan ini adalah menyampaikan ilmu pengetahuan kepada siswa yang ditempatkan sebagai objek yang menerima apa yang diberikan guru. Biasanya guru menyampaikan informasi mengenai bahan pembelajaran dalam bentuk penjelasan dan penuturan lisan, yaitu dengan metode ceramah. Pembelajaran ekspositori menghendaki siswa dapat menangkap dan mengingat informasi yang telah diberikan guru, serta mengungkapkan kembali apa yang telah 
dimikinya menjadi respon yang ia berikan pada saat guru melontarkan pertanyaan. Disini terjadi komunikasi satu arah, karena itu proses belajar siswa kurang optimal sebab terbatas pada mendengarkan mencatat apa yang disampaikan guru.

Gulo (2008) menjelaskan bahwa dalam pembelajaran ekspositori, guru mengolah secara tuntas pesan/materi sebelum disampaikan di kelas sehingga peserta didik tinggal menerima saja. Suparman (2001) menjelaskan pembelajaran ekspositori adalah strategi kegiatan pembelajaran yang menempatkan guru sebagai sumber utama dan tunggal. Kegiatan pembelajaran dalam strategi pembelajaran ekspositori berlangsung menggunakan guru sebagai satu-satunya sumber belajar dan sekaligus bertindak sebagai penyaji isi pelajaran, tidak menggunakan sumber lainnya, kecuali garis-garis besar, isi dan jadwal pelajaran yang disampaikan pada permulaan pembelajaran, beberapa transparansi, lembar kertas yang berisi gambar, bagan atau lainnya yang digunakan untuk sebagai latihan selama proses pembelajaran.

Sudjana (2002) menjelaskan ciri-ciri pembelajaran ekspositori yaitu: (1) komunikasi yang digunakan dalam pembelajaran adalah komunikasi satu arah, (2) siswa mendengar dan mencatat, dan (3) siswa kurang keberanian bertanya. Selanjutnya Nurhadi (2003) menjelaskan ciri-ciri pembelajaran ekspositori yaitu: (1) siswa menerima informasi secara pasif, (2) prilaku dibangun atas kebiasaan, (3) keterampilan dikembangkan atas dasar latihan, dan (4) pengetahuan adalah penangkapan terhadap serangkaian fakta, konsep atau hukum yang berada di luar diri siswa. Selain itu dalam proses pembelajaran, nilai kebenaran yang terdapat dalam suatu ilmu pengetahuan bersifat absolut dan final, hal ini disebabkan siswa tidak memperhatikan pengalaman belajar apa yang harus dirangkaikan dalam pikiran siswa dengan demikian keberhasilan proses pembelajaran ditentukan siswa.

Lie (2004) menjelaskan asumsi yang mendasari penerapan strategi pembelajaran ekpositori adalah: (1) proses pembelajaran merupakan usaha memindahkan pengetahuan guru ke siswa (tugas seorang guru adalah menerima, guru, memberikan informasi dan mengharapkan siswa untuk menghafal dan mengingatnya), (2) siswa dianggap botol kosong yang siap diisi dengan pengetahuan (siswa adalah penerima pengetahuan pasif, guru memiliki pengetahuan yang nantinya dihafal oleh siswa), (3) mengelompokkan siswa (guru mengelompokkan siswa berdasarkan nilai dan masukan siswa dalam kategori, pengelompokkan yang homogen, siapa yang layak mengikuti unggulan dan siapa yang tidak layak), (4) memacu siswa dalam kompetisi (siswa bekerja keras untuk mengalahkan teman sekelasnya, siapa yang kuat, dia yang menang, orang tua pun saling bersaing menyombongkan anaknya masing-masing dan menonjolkan prestasi anaknya).

Pembelajaran ekspositori sebagaimana diungkapkan Suparno (2002) menggunakan penjelasan secara verbal, komunikasi biasanya bersifat satu arah, biasanya dilengkapi dengan audio visual, tanya jawab dan diskusi singkat. Pembelajaran ekspositori biasanya mengikuti langkah-langkah sebagai berikut: merumuskan tujuan pembelajaran, merumuskan materi pembelajaran, menerapkan strategi pembelajaran, menyusun alat bantu pembelajaran, (4) menetapkan waktu, (6) menyusun tes formatif, dan (7) melaksanakan pembelajaran.

$$
\text { Rivai (2007) menjelaskan }
$$

komunikasi interpersonal berorientasi pada perilaku hingga penekanannya sampai kepada proses informasi, dari satu orang kepada orang lain. Hal senada diungkapkan oleh Sopiah (2008) komunikasi interpersonal adalah pertukaran informasi yang terjadi di antara dua orang. Ketika komunikasi interpersonal berlangsung, setiap orang memiliki cara tersendiri dalam berhubungan dengan orang lain. Komunikasi interpersonal akan efektif jika setiap individu yang berkomunikasi mengetahui informasi secara jelas dan lengkap.

Muhammad (2007) bahwa komunikasi interpersonal adalah proses pertukaran informasi di antara seseorang dengan paling kurang seorang lainnya atau biasanya di antara dua orang yang dapat langsung diketahui balikannya. Hal ini senada dengan apa yang dikemukakan oleh Thoha (2003) mengemukakan bahwa komunikasi interpersonal merupakan proses penyampaian berita yang dilakukan oleh seseorang dan diterimanya berita tersebut oleh orang lain atau kelompok kecil dari orang-orang, dengan suatu akibat dan umpan balik yang segera.

Berkaitan dengan tujuan untuk komunikasi interpersonal sebagaimana dijelaskan Muhammad (2007) yaitu: (1) menemukan diri sendiri, (2) menemukan dunia 
luar, (3) membentuk dan menjaga hubungan yang penuh arti, (4) berubah sikap dan tingkah laku, (5) untuk bermain dan kesenangan, dan (6) untuk membantu. Selanjutnya Muhammad (2007) mengelompokkan komunikasi interpersonal atas empat, yakni: (1) interaksi intim. Interaksi intim termasuk komunikasi di antara teman baik, pasangan yang sudah menikah, anggota famili, dan orang-orang yang mempunyai ikatan emosional yang kuat. Di dalam organisasi, hubungan ini dikembangkan dalam bentuk komunikasi informal, (2). percakapan sosial, adalah interaksi untuk menyenangkan seseoarang secara sederhana dengan sedikit berbicara. Percakapan biasanya tidak begitu terlihat secara mendalam, (3) interogasi atau pemeriksaan, adalah interaksi antara seseorang yang ada dalam kontrol, yang meminta atau bahkan menuntut informasi daripada yang lain; dan (4) wawancara adalah salah satu bentuk komunikasi interpersonal dimana dua orang terlibat dalam percakapan yang berupa tanya jawab. Keempat kelompok komunikasi interpersonal masih sangat relevan dipakai oleh guru dalam proses belajar mengajar. Semuanya bergantung kepada siapa individu tersebut berkomunikasi, bagaimana kedekatannya, serta apa yang akan dikomunikasikan.

Robbins (2007) mengemukakan cara setiap individu melaksanakan komunikasi interpersonal, ada tiga diantaranya: (1) komunikasi lisan, dalam bentuk pidato, percakapan dua orang dan diskusi kelompok, dan keuntungannya adalah kecepatan dan umpan balik yang dihasilkannya, (2) komunikasi tertulis, dalam bentuk memo, surat, email, facebook, pengiriman faksimili, laporan berkala organisasi, pengumuman di papan buletin, atau alat lain yang dikirimkan via katakata atau simbol tertulis, dan (3) komunikasi nonverbal, dalam bentuk gerakan tubuh, intonasi atau tekanan pada kata-kata.

Komunikasi interpersonal yang efektif menurut Thoha (2003) dikenal dengan lima hal, yakni: (1) keterbukaan, (2) empati, (3) dukungan, (4) kepositifan, dan (5) kesamaan. Keterbukaan, ada dua aspek yang diperhatikan untuk menunjukkan kualitas keterbukaan. Pertama, aspek keinginan untuk terbuka bagi setiap orang yang berinteraksi dengan orang lain. Dengan keinginan untuk terbuka ini dimaksudkan agar diri masing-masing tidak tertutup dalam menerima informasi dan berkeinginan untuk menyampaikan informasi dari dirinya bahkan juga informasi mengenai dirinya kalau dipandang relevan dalam rangka pembicaraan interpersonal dengan lawan bicaranya. Aspek kedua adalah keinginan untuk menanggapi secara jujur semua stimuli yang datang kepadanya. Diam, tidak bereaksi, tidak mau mengkritik, atau bahkan tidak mau bergerak secara fisik barangkali mungkin tepat untuk situasi tertentu, tetapi dalam komunikasi interpersonal atau dalam percakapan sehari-hari barangkali akan membosankan.

Hipotesis dalam penelitian ini sebagai berikut: (1) Hasil belajar PKn siswa yang dibelajarkan dengan strategi pembelajaran inkuiri sosial lebih tinggi daripada hasil belajar PKn siswa yang dibelajarkan dengan strategi pembelajaran ekspositori; (2) Hasil belajar PKn siswa dengan komunikasi interpersonal tinggi lebih tinggi dari pada hasil belajar PKn siswa dengan komunikasi interpersonal rendah; (3) Terdapat interaksi antara strategi pembelajaran dan komunikasi interpersonal terhadap hasil belajar PKn.

\section{METODE}

Penelitian ini dilaksanakan di MTs Islamiyah Londut dan MTs Assyarif Kuala Beringin Kecamatan Kualuh Hulu Kabupaten Labuhanbatu Utara, baik untuk uji coba instrumen maupun pelaksanaan penelitian. Populasi penelitian ini adalah siswa MTs Islamiyah Londut Kecamatan Kualuh Hulu. Kelas yang dipilih adalah kelas VIII terdiri dari 3 kelas dengan jumlah 108 siswa dan MTs Assyarif Kuala Beringin Kecamatan Kualuh Hulu terdiri dari 3 kelas dengan jumlah 94 siswa. Setiap kelas dalam populasi memiliki karakteristik yang sama, artinya setiap kelas tidak memiliki siswa yang pernah tinggal kelas, siswa rata-rata memiliki umur yang tidak jauh berbeda secara siginifikan, menggunakan kurikulum pendidikan yang sama. Di samping itu pembagian kelas tidak dilakukan berdasarkan rangking, sehingga tidak terdapat kelas unggulan yang karakteristik siswanya berbeda.

Penelitian ini menggunakan metode eksperimen dengan rancangan quasi eksperimen disain faktorial $2 \times 2$. Alasan pemilihan rancangan quasi eksperimen adalah: (1) kelas yang dilaksanakan pembelajaran sudah terbentuk sebelum, dan (2) karakteristik siswa yang dikontrol hanya satu aspek yaitu komunikasi interpersonal. 
Melalui disain penelitian dibandingkan pengaruh strategi pembelajaran inkuiri sosial dan strategi pembelajaran ekspositori terhadap hasil belajar PKn ditinjau dari siswa. Strategi pembelajaran inkuiri sosial dan strategi pembelajaran ekspositori diperlakukan kepada kelompok siswa dengan komunikasi interperosnal yang berbeda. Strategi pembelajaran inkuiri sosial dan strategi pembelajaran ekspositori sebagai variabel bebas, komunikasi interpersonal sebagai variabel moderator dan perolehan hasil belajar dalam mata pelajaran PKn sebagai variabel terikat. Variabel-variabel tersebut selanjutnya akan dimasukkan di dalam disain penelitian sebagaimana terlihat pada Tabel 1 .

Tabel 1. Rancangan Ekperimen Desain Faktorial 2 x 2

\begin{tabular}{|c|c|c|}
\hline \multirow{2}{*}{ Komunikasi Interpersonal $(\mathbf{B})$} & \multicolumn{2}{|c|}{ Strategi Pembelajaran $(A)$} \\
\cline { 2 - 3 } & Inkuiri Sosial $\left(\mathrm{A}_{1}\right)$ & Ekspositori $\left(\mathrm{A}_{2}\right)$ \\
\hline Tinggi $\left(\mathrm{B}_{1}\right)$ & $\mathrm{A}_{1} \mathrm{~B}_{1}$ & $\mathrm{~A}_{2} \mathrm{~B}_{1}$ \\
\hline Rendah $\left(\mathrm{B}_{2}\right)$ & $\mathrm{A}_{1} \mathrm{~B}_{2}$ & $\mathrm{~A}_{2} \mathrm{~B}_{2}$ \\
\hline
\end{tabular}

Keterangan:

A : Strategi pembelajaran

B : Komunikasi interpersonal

$\mathrm{A}_{1} \quad$ : Strategi pembelajaran inkuiri sosial

$\mathrm{A}_{2} \quad$ : Strategi pembelajaran ekspositori

$\mathrm{B}_{1} \quad$ : Komunikasi interpersonal tinggi

$\mathrm{B}_{2} \quad$ : Komunikasi interpersonal rendah

$\mathrm{A}_{1} \mathrm{~B}_{1}$ : Hasil belajar PKn siswa yang diajar dengan strategi pembelajaran inkuiri sosial pada siswa dengan komunikasi interpersonal tinggi

$A_{1} \quad B_{2}$ : Hasil belajar siswa PKn siswa yang diajar dengan strategi pembelajaran inkuiri sosial pada siswa dengan komunikasi interpersonal rendah

$A_{2} B_{1}$ : Hasil belajar PKn siswa yang diajar dengan strategi pembelajaran ekspositori pada siswa dengan komunikasi interpersonal tinggi

$\mathrm{A}_{2} \mathrm{~B}_{2}$ : Hasil belajar PKn siswa yang diajar dengan strategi pembelajaran ekspositori pada siswa dengan komunikasi interpersonal rendah

Teknik analisis data yang digunakan adalah teknik statistik deskriptif dan inferensial. Teknik statistik deskriptif digunakan untuk mendeskripsikan data, antara lain: nilai rata-rata (mean), median, modus, varians dan simpangan baku. Teknik statistik inferensial digunakan untuk menguji hipotesis penelitian, dimana teknik Inferensial yang digunakan adalah teknik Analisis Varians dua jalur (disain faktorial $2 \times 2$ ) dengan taraf signifikan 0,05 .

Sebelum pengujian hipotesis dilakukan pengujian persyaratan analisis meliputi uji normalitas dan uji homogenitas. Uji normalitas menggunakan uji Lilliefors, sedangkan untuk uji homogenitas menggunakan uji Fisher dan uji Bartlett. Setelah melakukan pengujian persyaratan analisis, selanjutnya dilakukan pengujian Anava 2 jalur, selanjutnya dilakukan uji lanjut dengan menggunakan uji Scheffe karena jumlah anggota sampel dalam setiap sel berbeda.

Untuk keperluan pengujian hipotesis, dirumuskan hipotesis statistik sebagai berikut:
a. Ho : $\mu A_{1}=\mu A_{2}$
Ha: $\mu A_{1}>\mu A_{2}$
b. Ho : $\mu \mathrm{B}_{1}=\mu \mathrm{B}_{2}$
Ha : $\mu \mathrm{B}_{1}>\mu \mathrm{B}_{2}$
c. Ho: $\mathrm{A}><\mathrm{B}=0$
$\mathrm{Ha}: \mathrm{A}><\mathrm{B} \neq 0$

Keterangan:

$\mu \mathrm{A}_{1}=$ rata-rata hasil belajar PKn yang diajar dengan strategi pembelajaran inkuiri sosial

$\mu \mathrm{A}_{2}=$ rata-rata hasil belajar PKn yang diajar dengan strategi pembelajaran ekspositori

$\mu \mathrm{B}_{1}=$ rata-rata hasil belajar PKn siswa dengan komunikasi interpersonal tinggi

$\mu B_{2}=$ rata-rata hasil belajar PKn siswa dengan komunikasi interpersonal rendah

\section{HASIL DAN PEMBAHASAN}

Pengujian hipotesis penelitian pertama, kedua dan ketiga dilakukan dengan menggunakan ANAVA dua jalur kemudian dilakukan uji lanjut dengan menggunakan uji Scheffe. Perhitungan selengkapnya dapat dilihat Lampiran 11 halaman 176. Rangkuman hasil perhitungannya dapat dilihat pada Tabel 2 . 
Tabel 2. Rangkuman Perhitungan Anava Faktorial 2 x 2

\begin{tabular}{|c|c|c|c|c|c|}
\hline Sumber Variasi & Dk & Jk & Rjk & F hitung & F tabel $_{(\mathbf{1}, 114)}(\boldsymbol{\alpha}=\mathbf{0 , 0 5})$ \\
\hline Strategi Pembelajaran & 1 & 144,88 & 144,88 & 7,03 & 3,928 \\
Komunikasi Interpersonal & 1 & 918,64 & 918,64 & 44,63 & \\
Interaksi & 1 & 309,69 & 309,69 & 15,04 & \\
Galat & 114 & 2346,57 & 20,58 & & \\
Total & 117 & 3719,78 & - & & \\
\hline
\end{tabular}

Berdasarkan rangkuman di atas maka dirinci pengujian hipotesis berikut:

Pengujian hipotesis pertama yaitu: hasil belajar PKn siswa yang diajar dengan strategi pembelajaran inkuiri sosial lebih tinggi daripada hasil belajar PKn siswa yang diajar dengan strategi pembelajaran ekspositori. Hipotesis statistiknya adalah:

Ho : $\mu \mathrm{A}_{1}=\mu \mathrm{A}_{2}$

$\mathrm{Ha}: \mu \mathrm{A}_{1}>\mu \mathrm{A}_{2}$

Berdasarkan perhitungan Anava faktorial 2 x 2 diperoleh F-hitung $=7,03$ sedangkan nilai $\mathrm{F}$-tabel $=3,928$ untuk $\mathrm{dk}$ $(1,114)$ dan taraf nyata $\alpha=0,05$. Ternyata nilai $\mathrm{F}_{\text {hitung }}=7,03>\mathrm{F}_{\text {tabel }}=3,928$ sehingga pengujian hipotesis menolak Ho dan menerima Ha. Dengan demikian dapat ditarik simpulan bahwa hasil belajar PKn siswa yang diajar dengan strategi pembelajaran inkuiri sosial lebih tinggi dibandingkan dengan hasil belajar PKn siswa yang diajar dengan strategi ekspositori teruji kebenarannya. Hal ini juga terlihat dari rata-rata hasil belajar PKn siswa yang diajar dengan strategi pembelajaran inkuiri sosial $(\bar{X}=70,93)$ lebih tinggi dari hasil belajar PKn siswa yang diajar dengan strategi pembelajaran ekspositori $(\bar{X}=69,69)$.

Pengujian hipotesis kedua yaitu: hasil belajar PKn siswa dengan komunikasi interpersonal tinggi lebih tinggi dari pada hasil belajar PKn siswa dengan komunikasi interpersonal rendah. Hipotesis statistiknya adalah:

Ho : $\mu \mathrm{B}_{1}=\mu \mathrm{B}_{2}$

$\mathrm{Ha}: \mu \mathrm{B}_{1}>\mu \mathrm{B}_{2}$

\section{Hasil Belajar}

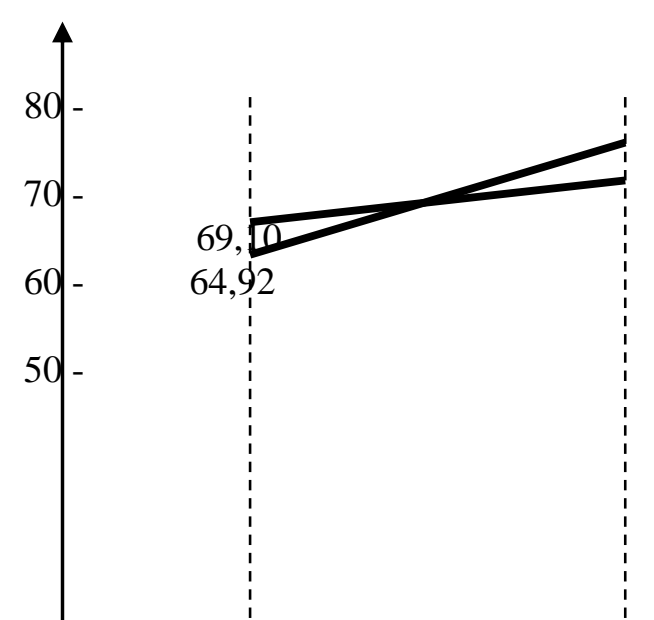

Berdasarkan perhitungan anava faktorial $2 \times 2$ diperoleh F-hitung $=44,63$ sedangkan nilai $\mathrm{F}$-tabel $=3,928$ untuk $\mathrm{dk}$ $(1,114)$ dan taraf nyata $\alpha=0,05$. ternyata nilai $\mathrm{F}_{\text {hitung }}=44,63>\mathrm{F}_{\text {tabel }}=3,928$ sehingga pengujian hipotesis menolak Ho dan menerima Ha. Dengan demikian dapat ditarik simpulan bahwa hasil belajar PKn siswa dengan komunikasi interpersonal tinggi lebih tinggi dari pada hasil belajar PKn siswa dengan komunikasi interpersonal rendah teruji kebenarannya. Hal ini juga terlihat dari rata-rata hasil belajar PKn siswa dengan komunikasi interpersonal tinggi ( $\bar{X}=73,42$ ) lebih tinggi dari hasil belajar PKn siswa dengan komunikasi interpersonal rendah ( $\bar{X}=67,80)$.

Pengujian hipotesis ketiga yaitu: terdapat interaksi antara strategi pembelajaran dan komunikasi interpersonal terhadap hasil belajar PKn siswa.

Hipotesis statistknya adalah:

Ho: $\mathrm{A}><\mathrm{B}=0$

Ha : $\mathrm{A}><\mathrm{B} \neq 0$

Berdasarkan perhitungan anava faktorial $2 \times 2$ diperoleh F-hitung $=15,04$ sedangkan nilai F-tabel $=3,928$ untuk dk $(1,114)$ dan taraf nyata $\alpha=0,05$. ternyata nilai F-hitung $=15,04$ $>$ F-tabel $=3,928$ sehingga pengujian hipotesis menolak Ho dan menerima Ha. Dengan demikian dapat ditarik simpulan bahwa terdapat interaksi antara strategi pembelajaran dan komunikasi interpersonal terhadap hasil belajar PKn teruji kebenarannya. Bentuk interaksi tersebut dapat disajikan pada gambar 1.

\section{$75,00 \quad$ Inkuiri Sosial \\ 71,77 Ekspositori}


$40-$

$30-$

$20-$

$10-$

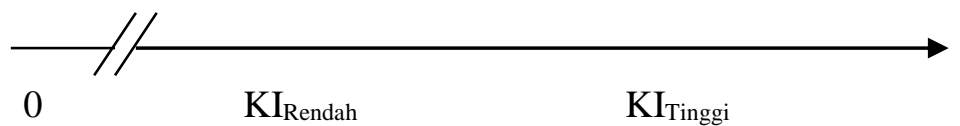

Gambar 1. Interaksi Strategi Pembelajaran Dan Komunikasi Interpersonal

Dengan terujinya secara signifikan interaksi antara strategi pembelajaran dan komunikasi interpersonal terhadap hasil belajar PKn, maka dilakukan uji lanjut. Sehubungan dengan jumlah sampel (n) pada setiap kelompok tidak sama, maka dilakukan uji lanjut dengan menggunakan uji Scheffe. Hasil perhitungan uji lanjut untuk setiap kelompok yang dibandingkan disajikan pada Tabel 3.

Tabel 3. Rangkuman Uji Scheffe

\begin{tabular}{|l|l|c|c|c|}
\hline \multicolumn{2}{|c|}{ Hipotesis Statistik } & $\mathrm{F}_{\text {-hitung }}$ & $\begin{array}{c}\mathrm{F}_{\text {-tabel }(3,114)} \\
(\alpha=0,05)\end{array}$ & Keterangan \\
\hline $\mathrm{H}_{\mathrm{O}: \mu 11=\mu 12}$ & $\mathrm{Ha}_{: \mu 11>\mu 12}$ & 2,03 & 2,688 & Tidak Signifikan \\
\hline $\mathrm{H}_{\mathrm{O}: \mu 11=\mu 21}$ & $\mathrm{Ha}: \mu 11>\mu 21$ & 7,17 & 2,688 & Signifikan \\
\hline $\mathrm{H}_{\mathrm{O}: \mu 11=\mu 22}$ & $\mathrm{Ha}: \mu 11>\mu 22$ & 5,29 & 2,688 & Signifikan \\
\hline $\mathrm{H}_{\mathrm{O}: \mu 12=\mu 21}$ & $\mathrm{Ha}: \mu 12>\mu 21$ & 4,02 & 2,688 & Signifikan \\
\hline $\mathrm{H}_{\mathrm{O}: \mu 12=\mu 22}$ & $\mathrm{Ha}_{: \mu 12>\mu 22}$ & 1,85 & 2,688 & Tidak Signifikan \\
\hline $\mathrm{H}_{\mathrm{O}: \mu 21=\mu 22}$ & $\mathrm{Ha}: \mu 21>\mu 22$ & 3,24 & 2,688 & Signifikan \\
\hline
\end{tabular}

Keterangan:

$\mu 11=$ Rata-rata hasil belajar kelompok siswa yang diajar dengan strategi pembelajaran Inkuiri Sosial dan Komunikasi Interpersonal tinggi

$\mu 12=$ Rata-rata hasil belajar kelompok siswa yang diajar dengan strategi pembelajaran Ekspositori dan Komunikasi Interpersonal tinggi

$\mu 21$ = Rata-rata hasil belajar kelompok siswa yang diajar dengan strategi pembelajaran Inkuiri Sosial dan Komunikasi Interpersonal rendah

${ }_{22}$ = Rata-rata hasil belajar kelompok siswa yang diajar dengan strategi pembelajaran Ekspositori dan Komunikasi Interpersonal rendah Berdasarkan hasil uji lanjut dengan uji

Scheffe di atas maka dapat disimpulkan bahwa dari enam kombinasi pengujian lanjut maka terdapat empat pengujian uji lanjut yang menunjukkan hasil signifikan dan dua pengujian uji lanjut menunjukkan hasil yang tidak signifikan.

\section{PEMBAHASAN}

Hasil pengujian hipotesis pertama menunjukkan hasil belajar PKn siswa yang diajar dengan strategi pembelajaran inkuiri sosial lebih tinggi daripada hasil belajar PKn siswa yang diajar dengan strategi pembelajaran ekspositori, dengan rata-rata hasil belajar PKn siswa yang diajar dengan strategi pembelajaran inkuiri sosial ( $\bar{X}=70,93$ ) lebih tinggi daripada ratarata hasil belajar PKn siswa yang diajar dengan strategi pembelajaran ekspositori $(\bar{X}=69,69)$. Hal ini menunjukkan bahwa strategi pembelajaran inkuiri sosial terbukti efektif dapat meningkatkan hasil belajar PKn siswa. Hasil temuan ini menunjukkan bahwa untuk mengajarkan materi ajar PKn lebih tepat menggunakan strategi pembelajaran inkuiri sosial daripada dengan strategi pembelajaran ekspositori. Hal ini sejalan dengan penjelaskan Wena (2009) strategi pembelajaran inkuiri sosial bertujuan menumbuhkembangkan pengetahuan dan keterampilan siswa dalam 
melakukan eksplorasi terhadap gejala-gejala sosial yang multikompleks. Selanjutnya Wena (2009) menjelaskan bahwa: (1) strategi pembelajaran inkuiri sosial dirancang untuk meningkatkan kemampuan dan keterampilan siswa dalam memecahkan masalah-masalah sosial, (2) beberapa hasil penelirian menunjukkan bahwa strategi pembelajaran inkuiri sosial terbukti efektif meningkatkan kemampuan dan keterampilan siswa dalam memecahkan masalah-masalah sosial, dan (3) strategi pembelajaran inkuiri sosial merupakan sinkronisasi antara teori mengajar dan teori belajar yang memiliki prosedur yang sistematis dan mudah diterapkan oleh pengajar.

Strategi pembelajaran inkuiri sosial dapat mendorong siswa untuk aktif belajar karena siswa dapat mencari informasi-informasi yang beragam dan beraneka sumber. Di samping itu strategi pembelajaran inkuiri sosial bertujuan menumbuhkan partisipasi siswa dalam memecahkan isu atau masalah yang diajukan tenaga pengajar dalam pembelajaran, menumbuhkan diskusi di antara siswa dalam mencari penyebab dan solusi terhadap isu atau masalah tersebut. Oleh karena itu peran tenaga pengajar dalam pembelajaran inkuiri sosial sebagai fasilitator yang mengarahkan siswa untuk mengkonstruk sendiri pengetahuannya.

Temuan penelitian ini mendukung temuan penelitian Sinurat (2010) tentang peningkatan hasil belajar bahasa Inggris melalui penerapan metode simulasi pada topik personal life di sekolah menengah pertama negeri 1 Lumbanjulu Kabupaten Tobasa, menemukan adanya peningkatan hasil belajar bahasa Inggris melalui penerapan pembelajaran metode simulasi. Hal ini dapat dimaklumi karena melalui penerapan pembelajaran metode simulasi dapat meningkatkan partisipasi aktif siswa dalam pembelajaran yang pada gilirannya dapat menggiring keberhasilan dan ketercapaian tujuan pembelajaran itu sendiri.

Temuan penelitian ini juga mendukung penelitian terdahulu yang dilakukan Penelitian Yusmini (2009) tentang pengaruh penerapan model pembelajaran dan interaksi sosial terhadap hasil belajar Sosiologi siswa Madrasah Aliyah Kisaran menemukan hasil belajar Sosiologi siswa yang diajar dengan model pembelajaran simulasi sosial lebih tinggi dibandingkan dengan rata-rata hasil belajar Sosiologi siswa yang diajar dengan model pembelajaran konvensional. Dengan demikian model pembelajaran simulasi sosial lebih efektif diterapkan dalam pembelajaran Sosiologi guna meningkatkan hasil belajar Sosiologi siswa tanpa memperhatikan adanya perbedaan karakteristik siswa dalam hal ini adalah interaksi sosial.

Selanjutnya jika diperhatikan lebih lanjut bahwa pada pembelajaran strategi pembelajaran inkuiri sosial, maka rata-rata hasil belajar PKn siswa dengan komunikasi interpersonal tinggi ( $\bar{X}=75,00$ ) lebih tinggi daripada hasil belajar PKn siswa dengan komunikasi interpersonal rendah $(\bar{X}=64,92)$. Sedangkan pada strategi pembelajaran ekspositori, rata-rata hasil belajar PKn siswa dengan komunikasi interpersonal tinggi $(\bar{X}=$ 71,77) lebih tinggi daripada hasil belajar PKn siswa dengan komunikasi interpersonal rendah $(\bar{X}=69,10)$. Hal ini menunjukkan bahwa komunikasi interpersonal signifikan untuk membedakan hasil belajar PKn siswa, di mana siswa dengan komunikasi interpersonal tinggi lebih baik diajar dengan strategi pembelajaran inkuiri sosial, sedangkan untuk siswa dengan komunikasi interpersonal rendah lebih baik diajar dengan strategi ekspositori.

Pengujian hipotesis kedua menunjukkan bahwa hasil belajar PKn siswa dengan komunikasi interpersonal tinggi lebih tinggi dari pada siswa dengan komunikasi interpersonal rendah. Hasil ini membuktikan bahwa komunikasi interpersonal dalam belajar signifikan untuk membedakan hasil belajar. Komunikasi interpersonal dalam penelitian ini dikategorikan atas dua kategori yaitu tinggi dan rendah. Dari hasil analisis data secara keseluruhan diperoleh rata-rata hasil belajar PKn siswa dengan komunikasi interpersonal tinggi ( $\bar{X}=73,42$ ) lebih tinggi daripada hasil belajar PKn siswa dengan komunikasi interpersonal rendah $(\bar{X}=67,80)$. Hal ini berindikasi bahwa siswa dengan komunikasi interpersonal tinggi secara rata-rata mempunyai hasil belajar PKn yang lebih baik dibandingkan dengan siswa dengan komunikasi interpersonal rendah. Dengan demikian siswa dengan komunikasi interpersonal tinggi lebih memahami dan menguasai materi ajar dibandingkan siswa dengan komunikasi interpersonal rendah.

Komunikasi interpersonal siswa merupakan faktor yang penting dalam pembelajaran inkuiri sosial yang menuntut interaksi dan komunikasi di antara siswa. Oleh 
karenanya siswa dengan komunikasi interpersonal tinggi memiliki kemampuan dalam berkomunikasi, mencurahkan pendapatnya. Siswa yang memiliki komunikasi interpersonal berciri utama adanya kecakapan berbicara dengan jelas, teratur dan lancar serta memiliki perbendaharaan kata-kata yang baik. Hal ini senada dengan penjelasan Sopiah (2008) bahwa komunikasi interpersonal adalah pertukaran informasi yang terjadi di antara dua orang. Ketika komunikasi interpersonal berlangsung, setiap orang memiliki cara tersendiri dalam berhubungan dengan orang lain. Komunikasi interpersonal akan efektif jika setiap individu yang berkomunikasi mengetahui informasi secara jelas dan lengkap.

Temuan penelitian ini mendukung penelitian sebelumnya yang dilakukan Payong (2005) tentang Pengaruh Strategi Pembelajaran Kolaboratif dan Kompetitif dan Komunikasi Interpersonal Terhadap Hasil Belajar PPKn Siswa SMA 03 Jakarta menemukan bahwa siswa yang memiliki komunikasi interpersonal tinggi, maka strategi pembelajaran kolaboratif memberikan pengaruh terhadap hasil belajar yang tinggi dibandingkan dengan strategi kompetitif. Namun bagi siswa yang memiliki komunikasi interpersonal rendah, baik strategi kolaboratif maupun strategi kompetitif tidak memiliki perbedaan pengaruh.

Pengujian hipotesis ketiga terdapat interaksi antara strategi pembelajaran dan komunikasi interpersonal dalam mempengaruhi hasil belajar PKn siswa. Apabila dilihat ratarata hasil belajar PKn pada kelompok siswa dengan komunikasi interpersonal tinggi yang diajar dengan strategi pembelajaran inkuiri sosial $(\bar{X}=75,0)$ lebih tinggi dibandingkan dengan rata-rata hasil belajar kelompok siswa dengan komunikasi interpersonal tinggi yang diajar dengan strategi ekspositori $(\bar{X}=71,77)$. Kemudian rata-rata hasil belajar PKn pada kelompok siswa dengan komunikasi interpersonal rendah yang diajar dengan strategi pembelajaran inkuiri sosial $(\bar{X}=64,92)$ lebih rendah dibandingkan dengan rata-rata hasil belajar siswa dengan komunikasi interpersonal rendah yang diajar dengan strategi pembelajaran ekspositori $(\bar{X}=69,10)$. Temuan penelitian ini mendukung Penelitian Payong (2005) yang menemukan siswa yang memiliki komunikasi interpersonal tinggi, strategi pembelajaran kolaboratif memberikan pengaruh terhadap hasil belajar yang tinggi dibandingkan dengan strategi kompetitif.

\section{PENUTUP}

Pertama, rata-rata hasil belajar PKn siswa yang diajar dengan strategi pembelajaran inkuiri sosial lebih tinggi dibandingkan dengan ratarata hasil belajar siswa yang diajar dengan strategi pembelajaran ekspositori. Dengan demikian strategi pembelajaran inkuiri sosial lebih efektif diterapkan dalam pembelajaran PKn khususnya pada materi ajar pelaksanaan demokrasi dalam kehidupan sehari-hari daripada strategi pembelajaran ekspositori.

Kedua, rata-rata hasil belajar $\mathrm{PKn}$ siswa dengan kecenderungan tingkat komunikasi interpersonal tinggi secara keseluruhan baik yang diajar dengan strategi pembelajaran inkuiri sosial dan strategi pembelajaran ekspositori lebih tinggi dibandingkan dengan rata-rata hasil belajar $\mathrm{PKn}$ siswa dengan kecenderungan tingkat komunikasi interpersonal rendah.

Ketiga, perbedaan pengaruh strategi pembelajaran dan komunikasi interpersonal adalah siswa dengan komunikasi interpersonal tinggi lebih tepat diajar dengan strategi pembelajaran inkuiri sosial daripada diajar dengan strategi pembelajaran ekspositori, sedangkan siswa dengan komunikasi interpersonal rendah lebih baik diajar dengan strategi pembelajaran ekspositori daripada diajar dengan strategi pembelajaran inkuiri sosial.

\section{DAFTAR PUSTAKA}

Dick, W. Carey, L. dan Carey, J. 2005. The Systematic Design of Instruction. Fouth Edition. New York: Harper Collin College Publisher

Djamarah, S.B. dan Zain, A. 2002. Strategi Belajar Mengajar. Jakarta: Rineka Cipta

Gagne, R.M. \& Briggs, L.J. 1979. Principles of Instructional Design. New York: Holt Rinehart and Winston

Gulo, W. 2008. Strategi Belajar Mengajar. Jakarta: Grasindo

Hamalik, O. 2004. Proses Belajar Mengajar. Jakarta: Bumi Aksara 2003. Kurikulum dan Pembelajaran. Jakarta: Bumi Aksara

Krathwohl, Bloom, B.S dan Masria. 1964. Taxonomy of Educational objectives: the classification of Educational Goals. New York: McKay 
Lie, A. 2004. Cooperative Learning (Mempraktikkan Cooperative Learning di Ruang-Ruang Kelas). Jakarta: Grasindo

Merill, M.D. 1981. A Lesson Based on the Component Display Theory. New Jersey: Lawrence Erlbaum Ass.

Muhammad, A. 2007. Komunikasi Organisasi. Jakarta: Bumi Aksara

Mulyati. 2005. Psikologi Belajar. Yogyakarta: Andi Nurhadi. 2003. Contextual Teaching Learning. Jakarta: Kementerian Pendidikan Nasional

Reigeluth, C.M. 1983. Instructional Design Theories and Models: An Overview of Their Current Status, Instructional Design: What Is it And Why is it?, New Jersey: Publisher Hilsdale

Rivai, V. 2007. Kepemimpinan dan Prilaku Organisasi. Jakarta: Raja Grafindo Persada

Robbins, S.P. 2007. Prilaku Organisasi, Edisi Kesepuluh Alih Bahasa: Benyamin Molan. Indonesia: Macanan Jaya Cemerlang

Rohani, A. dan Ahmadi, A. 2005. Pengelolaan Pengajaran. Jakarta: Rineka Cipta

Romizowski, A.Z. 1981. Designing Instructional System. New York: Nichol Publishing Company

Sanjaya, W. 2007. Strategi Pembelajaran Berorientasi Standar Proses Pendidikan. Jakarta: Kencana Prenada Media Group

Seels, B.C. and Richey, R.C. 1994. Instructional Technology, The Defenition and Domains of The Field, Washington. Terjemahan. Yusufhadi Miarso dkk

Slavin, R.E. (2009). Educational Psychology, Theory and Practice. Eight Edition. Psikologi Pendidikan, Teori dan Praktek. Penerjemah: Marianto Samosir. Jakarta: Indeks

Snelbecker, E.G. 1974. Learning Theory, Instructional Theory and Psychoeducational Design, New York: Mc Graw Hill

Sopiah. 2008. Perilaku Organisasional. Yogyakarta: Andi Offset

Sudjana, N. 2002. Dasar-Dasar Proses Belajar Mengajar. Jakarta; Sinar Baru Algensindo

Sukmadinata, N.S. 2006. Metode Penelitian Pendidikan. Bandung: Remaja Rosdakarya

Suparman, A. 2001. Desain Instrusional, Jakarta: Universitas Terbuka

Suparno, P. 2002. Filsafat Konstruktivisme Dalam Pendidikan, Yogyakarta: Kanisius

Surapranata, S. 2004. Analisis Validitas, Reliabilitas dan Interpretasi Hasil Tes, Bandung: Remaja Rosdakarya

Suryabrata, S. 2002. Psikologi Pendidikan. Jakarta: Raja Grafindo Persada

Syah, M. 2004. Psikologi Belajar. Jakarta: Raja Grafindo Persada

Thoha, M. 2003. Prilaku Organisasi, Konsep Dasar Dan Aplikasinya. Jakarta: Rajagrafindo Persada

Wena, M. 2009. Strategi Pembelajaran Inovatif Kontemporer. Jakarta: Bumi Aksara 